\title{
EVAPOTRANSPIRATION OF FULL-, DEFICIT-IRRIGATED AND DRYLAND COTTON ON THE NORTHERN TEXAS HIGH PLAINS ${ }^{1}$
}

\author{
T.A. Howell \\ S. R. Evett \\ J. A. Tolk \\ A. D. Schneider ${ }^{2}$
}

\begin{abstract}
Cotton (Gossypium hirsutum L.) is beginning to be produced on the Northern Texas High Plains as a lower water-requiring crop while producing an acceptable profit. Cotton is a warm season, perennial species produced like an annual yet it requires a delicate balance of water and water deficit controls to most effectively produce high yields in this thermally limited environment. This study measured the water use of cotton in near-fully irrigated, deficiently irrigated, and dryland regimes in a Northern Texas High Plains environment, which has a shortened cotton producing season, using precision weighing lysimeters in 2000 and 2001. The irrigated regimes were irrigated with a lateral-move sprinkler system. The water use data were used to develop crop coefficient data and compared with the FAO-56 method for estimating crop water use. Cotton yield, water use, and water use efficiency was found to be as good in this region as other more noted cotton regions. FAO-56 ET prediction procedures performed better for the more fully irrigated treatments in this environment.
\end{abstract}

\section{INTRODUCTION}

Irrigation supplies from the northern High Plains Aquifer (Ogallala Aquifer) are declining due to water mining and the limited aquifer recharge. Producers are seeking alternate crops in the northern portion of the Southern High Plains that might reduce water consumption and extend the aquifer's useful life. Corn (Zea mays $\mathrm{L}$.) is widely produced in the region with exceptionally high yields (USDA-NASS, 2001), but it has a large irrigation requirement (Howell et al., 1997). Cotton (Gossypium hirsutum L.) offers potentially equal gross incomes while requiring less irrigation water and the ability to be produced under dryland conditions while corn is not a reliable dryland crop in this region. The Northern

\footnotetext{
${ }^{1}$ Contribution from the USDA-ARS, Southern Plains Area, Conservation and Production Research Laboratory, Bushland, TX U.S.A.

${ }^{2}$ Research Leader (Supervisory Agricultural Engineer), Soil Scientist, Plant Physiologist, and Agricultural Engineer (retired) [currently, Water Resource Engineer, Puyallup, WA 98373], USDA-ARS, Conservation and Production Research Laboratory, P. O. Drawer 10, Bushland, TX 79012. Email: tahowell@cprl.ars.usda.gov.
} 
Texas High Plains is adjacent to the largest contiguous cotton-producing region in the U.S., but it has a growing season length and thermal environment that is marginal for cotton. Nevertheless, producers are moving cotton production farther north in search of an alternate, economical crop. This region is far from ideal for cotton (Peng et al.,1989) with its short season, cool temperatures, high evaporative demand, and water scarcity (both from irrigation and growing season rainfall).

FAO-56 evapotranspiration (ET) methods (Allen et al., 1998) replaced the FAO-24 (Doorenbos and Pruitt, 1975) methods for estimating crop water use and proposed using the dual crop coefficient approach based on Wright (1982).

FAO-56 used more precise definitions for the separation of soil water evaporation and crop transpiration from the lumped crop evapotranspiration and used the "straight-line" crop coefficient $\left(\mathrm{K}_{c}\right)$ approach (segmented lines opposed to curves) from FAO-24. Both FAO-56 and FAO-24 are based on "grass reference" ET (termed $\mathrm{ET}_{0}$ ) with FAO-24 being based on a Penman equation and FAO-56 being based on the Penman-Monteith (PM) equation for a specified grass height [4.7 in. $(0.12 \mathrm{~m})]$, surface resistance $\left[230 \mathrm{~s} \mathrm{ft}^{-1}\left(70 \mathrm{~s} \mathrm{~m}^{-1}\right)\right]$, albedo $(0.23)$, and constant latent heat flux $\left[585 \mathrm{cal} \mathrm{g}^{-1}\left(2.45 \mathrm{MJ} \mathrm{kg}^{-1}\right)\right]$. These ET methods are intended to improve irrigation scheduling programs such as Jensen et al. (1970) and Jensen et al. (1971). Although several methods are employed to express the time base for $\mathrm{K}_{c}$ curves, FAO-56 used a day scale while others have used a thermal scale based on growing degree days (GDD) (Sammis et al., 1985; Stegman, 1988; Ayars and Hutmacher, 1994; Slack et al., 1996; and Hunsaker, 1999). The GDD scale has been reported to improve inter-site and inter-seasonal transferability of $K_{c}$ curves. Methods for computing GDDs differ significantly, including time base (hour or shorter to daily values), methods for computing the GDDs (Fry, 1983), and varying base and upper threshold temperatures used.

Hunsaker (1999) developed $K_{c}$ curves for a short-season cotton variety in Arizona based on the California Irrigation Management System (CIMIS) hourly Penman equation (Snyder and Pruitt, 1985) for both the FAO-56 "straight line" and GDD based $\mathrm{K}_{\mathrm{c}}$ methods. Their $\mathrm{K}_{\mathrm{c}}$ values were larger than those proposed in FAO-56 for cotton. Allen (1999) applied the FAO-56 procedures to a large irrigation district in the western U.S., and he found an $8 \%$ over-estimate, which he attributed to actual crop conditions not fully representing the more "pristine" conditions assumed in FAO-56. Tolk and Howell (2001) found the dual $\mathrm{K}_{\mathrm{c}}$ approach for sorghum (Sorghum bicolor (L.) Moench) superior compared with the single $\mathrm{K}_{\mathrm{c}}$ approach using the FAO-56 methodology. The FAO-56 soil water evaporation procedures tended to over-estimate evaporation early in the season, and the "straight line" water limits on ET (based on Kerr et al., 1993) tended to over-estimate simulated effects on ET, particularly at the end of the season. Grismer (2002) reported that cotton $\mathrm{K}_{\mathrm{c}}$ values that were measured in Arizona and California exceeded those reported in FAO-56 by $30-35 \%$ under non-waterstressed conditions, by $30 \%$ in CA under water stress, and by $20-25 \%$ in desert environments in $\mathrm{AZ}$ and $\mathrm{CA}$. 
Few studies besides Allen (1999 and 2000) and Tolk and Howell (2001) have evaluated the FAO-56 methods independently. The purpose of this paper is to report cotton water use amounts and rates in an environment not optimum for cotton and to compare the resulting water use rates in terms of the FAO-56 dual $\mathrm{K}_{\mathrm{c}}$ approach across three water regimes.

\section{MATERIALS AND METHODS}

\section{Agronomy and Treatments}

The study was conducted at the USDA-ARS Laboratory at Bushland, TX $\left[35^{\circ} 11^{\text {, }}\right.$ $\mathrm{N}$ lat.; $102^{\circ} 06^{\prime} \mathrm{W}$ long.; $3,840 \mathrm{ft}(1,170 \mathrm{~m})$ elev. above MSL]. ET was measured with two weighing lysimeters (Marek et al., 1988) each located in the center of 10.9 -ac (4.4-ha) [700 ft $(210 \mathrm{~m}) \mathrm{E}-\mathrm{W}$ by $700 \mathrm{ft}(210 \mathrm{~m}) \mathrm{N}-\mathrm{S}$ ] fields [four fields arranged in a square pattern] during the 2000 and 2001 seasons. The soil at this site is classified as Pullman clay loam [fine, mixed, superactive thermic Torrertic Paleustoll] (Unger and Pringle, 1981; Taylor et al., 1963) which is described as slowly permeable because of a dense B22 horizon about 1.0 to $1.6 \mathrm{ft}(0.3$ to 0.5 $\mathrm{m})$ below the surface. The plant available water holding capacity within the top $6.6 \mathrm{ft}(2.0 \mathrm{~m})$ of the profile is approximately $9.4 \mathrm{in} .(240 \mathrm{~mm})$ [7.9 in. $(-200 \mathrm{~mm})$ to $5.0-\mathrm{ft}(1.5-\mathrm{m})$ depth). A calcareous layer at about the $5.0 \mathrm{ft}(1.5 \mathrm{~m})$ depth limits significant rooting and water extraction below this depth. This soil is common to more than 2.9 million ac (1.2 million ha) of land in this region and about 1/3 of the sprinkler-irrigated area in the Texas High Plains (Musick et al., 1988). Weighing lysimeters offer one of the most accurate means to measure ET (Hatfield, 1980). Predominate wind direction is SW to SSW, and the unobstructed fetch (fallow fields or dryland cropped areas) in this direction exceeds $0.62 \mathrm{mi}$. $(1 \mathrm{~km})$. The field slope is less than 0.3 percent.

Two adjacent lysimeter fields (designated west and east) each contain two weighing lysimeters (designated NW \& SW and NE \& SE, respectively) were planted to cotton in each season. Each lysimeter field with its two sub-fields contained a weighing lysimeter in its center (Marek et al., 1987) that was $100 \mathrm{ft}^{2}$ $\left(9 \mathrm{~m}^{2}\right)$ in area and $8 \mathrm{ft}(2.3 \mathrm{~m})$ deep with monolithic cores. Both lysimeter fields were planted to the same variety and managed similarly. The west lysimeter field was dryland (DRY) with the north half (NW) in 30-in. (0.76-m) spaced rows and the south half (SW) in 10-in. $(0.25-\mathrm{m})$ spaced rows in 2000 and twin rows $10 \mathrm{in}$. $(0.25 \mathrm{~m})$ apart on $30 \mathrm{in} .(0.76-\mathrm{m})$ spaced rows in 2001 . The NW field was sown at rate of 183 seeds $\mathrm{ft}^{-2}\left(17\right.$ seeds $\left.\mathrm{m}^{-2}\right)$ [ 6.1 seeds per $\mathrm{ft}$ of row $(13$ seeds per meter of row)]. Data from the SW field are not being used in this study [i.e., only the cotton fields in 30 -in rows $(0.76-\mathrm{m})$ spaced rows is being used herein]. The east lysimeter field was irrigated in both years with the south half(SE) being irrigated to meet the crop water use (FULL) but allowed to reach boll cutout and dry down for maturity while the north half (NE) was irrigated at one-half the FULL rate, 
except for a few initial irrigations for establishment at the FULL rate, on the same days by using smaller sized nozzles on the irrigation spray heads to achieve approximately one-half the flow rate (i.e., one-half the peak application rate and one-half the application amount). The sowing rate was the same for the FULL and DEFICIT treatments at 226 seeds $\mathrm{ft}^{-2}\left(21\right.$ seeds $\left.\mathrm{m}^{-2}\right)$ [7.5 seeds per $\mathrm{ft}$ of row ( 16 seeds per meter of row)] in 2000 , but it was reduced slightly to 215 seeds $\mathrm{ft}^{2}$ ( 20 seeds $\mathrm{m}^{-2}$ ) [ 7.2 seeds per $\mathrm{ft}$ of row ( 15 seeds per meter of row)] in 2001. The lysimeters were sown at a thicker rate and hand thinned about two weeks after emergence to match field plant densities.

Table 1 summarizes the agronomic and management details. Cotton was grown in both lysimeter fields (Paymaster 2145 in both seasons) on rows spaced 30 in. $(0.76 \mathrm{~m})$ apart. In the east lysimeter field (SE and NE fields), rows were on raised beds and the furrows were diked to store irrigation and rainfall. In the NW field, rows were flat without beds or dikes. All field operations were performed with standard $15 \mathrm{ft}(4.6-\mathrm{m})$ row-crop field equipment, except in the immediate $320-\mathrm{ft}^{2}$ $\left(30-\mathrm{m}^{2}\right)$ area at each lysimeter where hand-cultural methods were required. Fertility and pest control were applied uniformly to the field area.

Table 1. Agronomic and management information.

\begin{tabular}{l|c|c|c|c}
\hline \multirow{2}{*}{ Category } & \multicolumn{2}{|c|}{2000} & \multicolumn{2}{c}{2001} \\
\cline { 2 - 5 } & Irrigated & Dryland & Irrigated & Dryland \\
\hline Apply herbicide & Apr. 27 & Apr. 26 & Apr. 27 & Apr. 30 \\
Plant & May 17 & May 16 & May 16 & May 17 \\
Emergence & May 26 & May 28 & May 28 & May 29 \\
Installed neutron tubes & May 31 & June 1 & May 29 & May 29 \\
Cultivate & July 6 & July 10 & NA & NA \\
Furrow dike installation & July 7 & NA & NA & NA \\
Begin deficit treatment & July 26 & NA & July 2 & NA \\
Harvest & Nov. 14 & Oct.18 & Oct. 30 & Oct. 22 \\
\hline
\end{tabular}

\section{Irrigations}

Irrigations were applied with a 10-span lateral-move sprinkler system (Lindsay Manufacturing, Omaha, NE) with an end-feed hose and aboveground, end guidance cable. The sprinkler system was aligned N-S, and irrigated E-W or W-E. The system was equipped with gooseneck fittings and spray heads (Nelson D3000, Walla Walla, WA) with medium grooved, concaved spray plates on drops

\footnotetext{
${ }^{3}$ The mention of trade or manufacturer names is made for information only and does not imply an endorsement, recommendation, or exclusion by USDAAgricultural Research Service
} 
located about $5 \mathrm{ft} 1.5 \mathrm{~m}$ above the ground and $60 \mathrm{in}$. (1.52) $\mathrm{m}$ apart. Each spray head was equipped with a $15-\mathrm{psi}(100-\mathrm{kPa})$ pressure regulator and a $2.2-\mathrm{lb} .(1-\mathrm{kg})$ polyethylene drop weight. Irrigations were scheduled to meet the ET water use rate (based on the lysimeter mass of the FULL treatment) and were typically applied in one to two $1.0 \mathrm{in}$. $(25-\mathrm{mm})$ applications per week. Irrigations were managed on the FULL treatment to minimize early water deficits with the available irrigation capacity while allowing the soil water profile to deplete in order to initiate boll cutout and to use the readily available soil water by maturity or just before frost. The FULL treatment did no completely meet the "potential" water demand late in the season to reduce vegetative growth in favor of boll filling and eventual opening of the bolls likely to mature by the season's end.

\section{Plant and Yield Sampling}

Plant samples from $11-16 \mathrm{ft}^{2}\left(1.0-1.5-\mathrm{m}^{2}\right)$ areas were obtained periodically to measure crop development. These field samples were taken at sites about 30 to $60 \mathrm{ft}(10$ to $20 \mathrm{~m})$ away from the lysimeters in areas of the field representative of the lysimeter vegetation. Leaf area index (LAI), crop height $(\mathrm{CH})$, and aboveground dry matter (DM) were measured from three samples. Final yield was measured by harvesting all the open bolls and aboveground plant matter from each lysimeter $\left[97 \mathrm{ft}^{2}\left(9 \mathrm{~m}^{2}\right)\right]$, and dry matter and yield at harvest were measured from adjacent plant samples. The seed cotton was ginned on a small research gin at the Texas Agricultural Experiment Station at Lubbock and fiber samples were analyzed by the Texas Tech University International Textile Center (data not reported here).

\section{Lysimeter Measurements}

Lysimeter mass was determined using a Campbell Scientific (Campbell Scientific, Inc., Logan, UT) model CR-7X data logger to measure and record the lysimeter load cell (Interface, Scottsdale, AZ) model SM-50, signal sampled at $0.5-\mathrm{Hz}(2 \mathrm{~s})$ frequency. The load cell signal was averaged for $5 \mathrm{~min}$ and composited to $30-\mathrm{min}$ means (reported on the mid point of the $30 \mathrm{~min}$, i.e. data were averaged from 0-30 minutes and reported at $15 \mathrm{~min}$ ), and the lysimeter mass resolution was $0.004 \mathrm{in}$. $(0.01 \mathrm{~mm})$, and its accuracy exceeded $0.002 \mathrm{in} .(0.05 \mathrm{~mm})$ (Howell et al., 1995a). Daily ET was determined as the difference between lysimeter mass losses (from evaporation and transpiration) and lysimeter mass gains (from irrigation, precipitation, or dew) divided by the lysimeter area $\left[97 \mathrm{ft}^{2}\left(9 \mathrm{~m}^{2}\right)\right]$. The lysimeters were calibrated prior to the experiment similarly to the methods used by Howell et al. (1995a) but not as detailed. A pump regulated to -17 in. $\mathrm{H}_{2} \mathrm{O}$ column $(-10 \mathrm{kPa})$ provided vacuum drainage, and the drainage effluent was held in two tanks suspended from the lysimeter (their mass was part of the total lysimeter mass) and independently weighed by load cells (drainage rate data are 
not reported here). ET for each 24-h period was multiplied by 1.02 to adjust the lysimeter area to the mid point between the two walls [0.39 in. (10 mm) air gap; 0.37 in. $(9.5 \mathrm{~mm})$ wall thickness; $98 \mathrm{ft}^{2}\left(9.18 \mathrm{~m}^{2}\right)$ area instead of $96.9 \mathrm{ft}^{2}\left(9.00 \mathrm{~m}^{2}\right)$ area)]. This correction would be applicable for full-cover crops, but it would not be necessary for bare soil conditions. Nevertheless, it was applied to all data uniformly.

\section{$\underline{\text { Soil Water Measurements }}$}

Soil water contents were measured periodically using a neutron probe (Campbell Pacific Nuclear, Martinez, CA) model 503DR Hydroprobe at 8 in. $(0.2-\mathrm{m})$ depth increments with 30 -s counts. Two access tubes were located in each lysimeter [read to $6.2 \mathrm{ft}(1.9 \mathrm{~m})$ depth] and four tubes were located in the field surrounding each lysimeter [read to $7.5-\mathrm{ft}(2.3-\mathrm{m})$ depth]. The probe was field calibrated for the Pullman soil using a method similar to that described by Evett and Steiner (1995).

\section{Climatic Data, Reference ET, and Crop Coefficients}

Solar radiation, wind speed, air temperature, dew point temperature, relative humidity, precipitation, and barometric pressure were measured at an adjacent weather station (Howell et al., 1995b) with an irrigated grass surface (cool-season lawn mixture containing bluegrass, perennial rye-grass, etc.). Reference ET (ETo) was computed with the FAO-56 equation using the exact formulas in Allen et al. (1998).

The crop ET (ET in $\left.\mathrm{mm} \mathrm{d}^{-1}\right)$ was computed as

$$
E T_{c}=\left(K_{c b} K_{s}+K_{e}\right) E T_{o}
$$

where $\mathrm{K}_{\mathrm{cb}}$ is the "basal" crop coefficient, $\mathrm{K}_{\mathrm{s}}$ is the soil water deficit factor, $\mathrm{K}_{\mathrm{c}}$ is the soil water evaporation factor, and $\mathrm{ET}_{0}$ is the grass reference ET in (in. day ${ }^{-1}$ or $\mathrm{mm}$ day ${ }^{-1}$ ). Values for $\mathrm{K}_{\mathrm{cb}}, \mathrm{K}_{\mathrm{s}}$, and $\mathrm{K}_{\mathrm{e}}$ were derived following Tolk and Howell (2001) (Table 2) for the Pullman soil and using guides from Allen et al. (1998) in the FAO-56 manual. A spreadsheet patterned after Appendix 8 in the FAO-56 manual was used for this similar to one developed for use in Tolk and Howell (2001). Stage lengths were estimated from the measured FULL treatment and based on phenologic growth stages of cotton (Hake et al., 1990). The $\mathrm{K}_{c b}$ values were fit to the few mean $K_{c}$ values for days without irrigations and were selected to match as closely as possible to those in FAO-56. The value for " $p$ " was 
reduced from 0.65 in FAO- 56 to 0.55 to initiate an ET reduction to better match field observations.

Table 2. Pullman soil parameters used with FAO-56 dual $\mathrm{K}_{\mathrm{c}}$ model (Tolk and Howell, 2001). See FAO-56 manual for parameter definitions (Allen et al., 1998)

\begin{tabular}{|l|l|c|}
\hline Parameter & Definition & Value and Unit \\
\hline FC & Field capacity & $0.33 \mathrm{~m} \mathrm{~m}^{-3}$ \\
PWP & Permanent wilting point & $0.20 \mathrm{~m} \mathrm{~m}^{-3}$ \\
$Z_{\mathrm{r}}$ & Root zone depth & $1.5 \mathrm{~m}$ \\
$\mathrm{Z}_{\mathrm{e}}$ & Evaporation zone depth & $0.15 \mathrm{~m}$ \\
TEW & Total evaporative water & $34.5 \mathrm{~mm}$ \\
REW & Readily evaporative water & $10 \mathrm{~mm}$ \\
TAW & Total available water & $195 \mathrm{~mm}$ \\
RAW & Readily available water & $107 \mathrm{~mm}$ \\
p & Water stress initiation & 0.55 (fraction) \\
\hline in. $\mathrm{ft}^{-1}=12^{*}\left(\mathrm{~m}^{3} \mathrm{~m}^{-3}\right)$ \\
$\mathrm{ft}=3.28^{*}(\mathrm{~m})$ \\
in. $=0.03937^{*}(\mathrm{~mm})$ \\
\hline
\end{tabular}

Growing degree-days were computed as the mean of the daily maximum and minimum air temperatures less the base temperature of $60^{\circ} \mathrm{F}\left(15.6^{\circ} \mathrm{C}\right)$ (Hake et al., 1990; Peng et al., 1989) that is widely used in the cotton community in the Southern High Plains. This GDD method differs from that used by Hunsaker (1999), and the methods described by Fry (1983), who provided some conversions for differing GDD methods.

\section{Model Performance Evaluation}

Tolk and Howell (2001) explained the desirability of the Legates and McCabe (1999) statistical procedure ( $E$; modified coefficient of model efficiency), but both that procedure and the Willmott (1981) method [D; coefficient of agreement] that used the error square terms were included. Also, standard statistical parameters - coefficient of determination $\left(r^{2}\right)$, standard deviation, mean, and root mean square error (RMSE) were used to characterize the data and the FAO-56 model performance. 


\section{RESULTS AND DISCUSSION}

\section{Weather and Climatic Conditions}

Both of the growing seasons were drought seasons for Bushland, but they were not atypical of the climatic variations experienced on the Southern Great Plains. The climatic conditions are given in Table 3 for the seasons, and the Bushland historical data are presented for comparison. Mean monthly temperatures were not greatly different from long-term monthly means despite the dry summers. After the slightly larger than normal rain in June of 2000 , the growing season was devoid of significant rains until late October, which was too late to help the 2000 crop. The 2001 rainfall was again below normal although early rains in May and June reduced the need for early irrigations. Wind speeds at the 2 -m elevation were greater than normal in the early 2000 season. The mean seasonal FAO-56 reference ET $\left(\mathrm{ET}_{0}\right)$ was almost identical in both years, although they had slightly differing temporal trends in daily $\mathrm{ET}_{\mathbf{0}}$.

\section{Crop Development}

Figures 1 and 2 illustrate the cotton development in each season, respectively. The 2000 crop was planted following alfalfa (Medicago sativa L.), which may have affected the growth and development. The alfalfa was plowed out during the 1999 fall and winter, but a few alfalfa plants remained that had to be treated postplanting with herbicides. In addition, the deeper rooting alfalfa had depleted the deep soil water [ $>5 \mathrm{ft}(1.5 \mathrm{~m})]$. The 2001 FULL treatment achieved a greater LAI, CH, and DM than it did in 2000. However, the DRY and DEFICIT treatments had almost the same growth patterns in both years. These cotton growth patterns are typical for the Texas High Plains, although we expected LAI for the FULL treatment in 2000 to be more like the pattern in 2001. The FULL treatment achieved a closed canopy in both seasons; however its canopy was taller in 2001 with significantly greater row width spread (as indicated by the LAI values; see Figs. 1 and 2). 
Table 3. Monthly climatic data summary of daily mean values for 2000 and 2001 compared with the 20-yr Bushland historical mean data.

\begin{tabular}{|c|c|c|c|c|c|c|c|c|}
\hline \multicolumn{9}{|l|}{2000} \\
\hline Month & $\begin{array}{c}\text { Max } \\
\text { Temp. } \\
\text { Tmax } \\
{ }^{\circ} \mathrm{C}\end{array}$ & $\begin{array}{l}\text { Min. } \\
\text { Temp. } \\
\text { Tmin } \\
{ }^{\circ} \mathrm{C} \\
\end{array}$ & $\begin{array}{l}\text { Dew } \\
\text { Point } \\
\text { Tdew } \\
{ }^{\circ} \mathrm{C} \\
\end{array}$ & $\begin{array}{c}\text { Solar } \\
\text { Rad. } \\
\text { MJ } \\
\mathrm{m}^{-2} \\
\mathrm{~d}^{-1} \\
\end{array}$ & $\begin{array}{l}2-\mathrm{m} \\
\text { Wind } \\
\mathrm{m} \mathrm{s}^{-1}\end{array}$ & $\begin{array}{c}\text { Barometric } \\
\text { Pressure } \\
\text { kPa } \\
\end{array}$ & $\begin{array}{l}\text { ETo } \\
\text { mm } \\
d^{-1}\end{array}$ & $\begin{array}{l}\text { Rain } \\
\mathrm{mm}\end{array}$ \\
\hline May & 29.5 & 11.0 & 5.6 & 26.6 & 5.12 & 88.1 & 8.17 & 11.4 \\
\hline June & 28.9 & 16.0 & 14.2 & 21.7 & 5.12 & 88.4 & 6.45 & 96.8 \\
\hline July & 33.2 & 17.9 & 14.2 & 26.1 & 3.91 & 88.5 & 7.68 & 26.2 \\
\hline August & 33.9 & 17.3 & 10.8 & 24.5 & 3.59 & 88.6 & 7.75 & 0.5 \\
\hline September & 31.1 & 12.6 & 5.2 & 21.2 & 3.68 & 88.5 & 6.74 & 0.0 \\
\hline October & 20.7 & 8.1 & 6.9 & 12.3 & 3.66 & 88.6 & 3.08 & 66.0 \\
\hline \multicolumn{9}{|l|}{2001} \\
\hline May & 25.4 & 10.4 & 10.6 & 24.3 & 4.04 & 88.3 & 5.38 & 75.7 \\
\hline June & 32.7 & 16.0 & 11.0 & 27.5 & 4.33 & 88.4 & 8.38 & 33.5 \\
\hline July & 35.1 & 19.3 & 12.7 & 26.6 & 3.64 & 88.5 & 8.36 & 3.6 \\
\hline August & 31.9 & 16.8 & 13.9 & 22.1 & 3.04 & 88.7 & 6.19 & 28.2 \\
\hline September & 29.2 & 12.4 & 10.7 & 20.5 & 3.44 & 88.6 & 5.52 & 12.2 \\
\hline October & 24.0 & 5.5 & 1.9 & 16.1 & 4.16 & 88.5 & 4.78 & 1.5 \\
\hline \multicolumn{9}{|c|}{ 20-yr Bushland Historical Means } \\
\hline May & 25.7 & 9.6 & $\mathrm{NA}$ & $24.7 \S$ & $4.34 \pi$ & NA & NA & 59.9 \\
\hline June & 30.1 & 14.7 & & 26.3 & 4.26 & & & 76.2 \\
\hline July & 32.3 & 16.9 & & 25.9 & 3.73 & & & 73.4 \\
\hline August & 31.4 & 16.4 & & 22.9 & 3.44 & & & 70.9 \\
\hline September & 27.6 & 11.9 & & 19.3 & 3.61 & & & 56.4 \\
\hline October & 21.8 & 5.3 & & 15.6 & 3.77 & & & 40.1 \\
\hline \multicolumn{9}{|c|}{$\begin{array}{l}\text { \$ } 28 \text {-yr mean } \\
\text { I } 12 \text {-yr mean }\end{array}$} \\
\hline \multicolumn{9}{|c|}{$\begin{array}{l}{ }^{\circ} \mathrm{F}=1.8^{*}\left({ }^{\circ} \mathrm{C}\right)+32 \\
\text { cal } \mathrm{cm}^{-2} \mathrm{day}^{-1}=23.89^{*}\left(\mathrm{MJ} \mathrm{m}^{-2} \mathrm{~d}^{-1}\right) \\
\text { in. } \mathrm{Hg}\left(60^{\circ} \mathrm{F}\right)=0.292^{*}(\mathrm{kPa}) \\
\mathrm{mph}=2.237^{*}\left(\mathrm{~m} \mathrm{~s}^{-1}\right) \\
\text { in. } \mathrm{d}^{-1}=0.03937^{*}\left(\mathrm{~mm} \mathrm{~d}^{-1}\right) \\
\text { in. }=0.03937^{*}(\mathrm{~mm})\end{array}$} \\
\hline
\end{tabular}

\section{Water Use, Yield, and Water Use Efficiency}

The seasonal water use, yield, and lysimeter water use efficiency (WUE) data are presented in Table 4. Grismer (2002) recently reviewed these types of data for cotton, emphasizing $\mathrm{AZ}$ and $\mathrm{CA}$ locations, but he included studies conducted in 


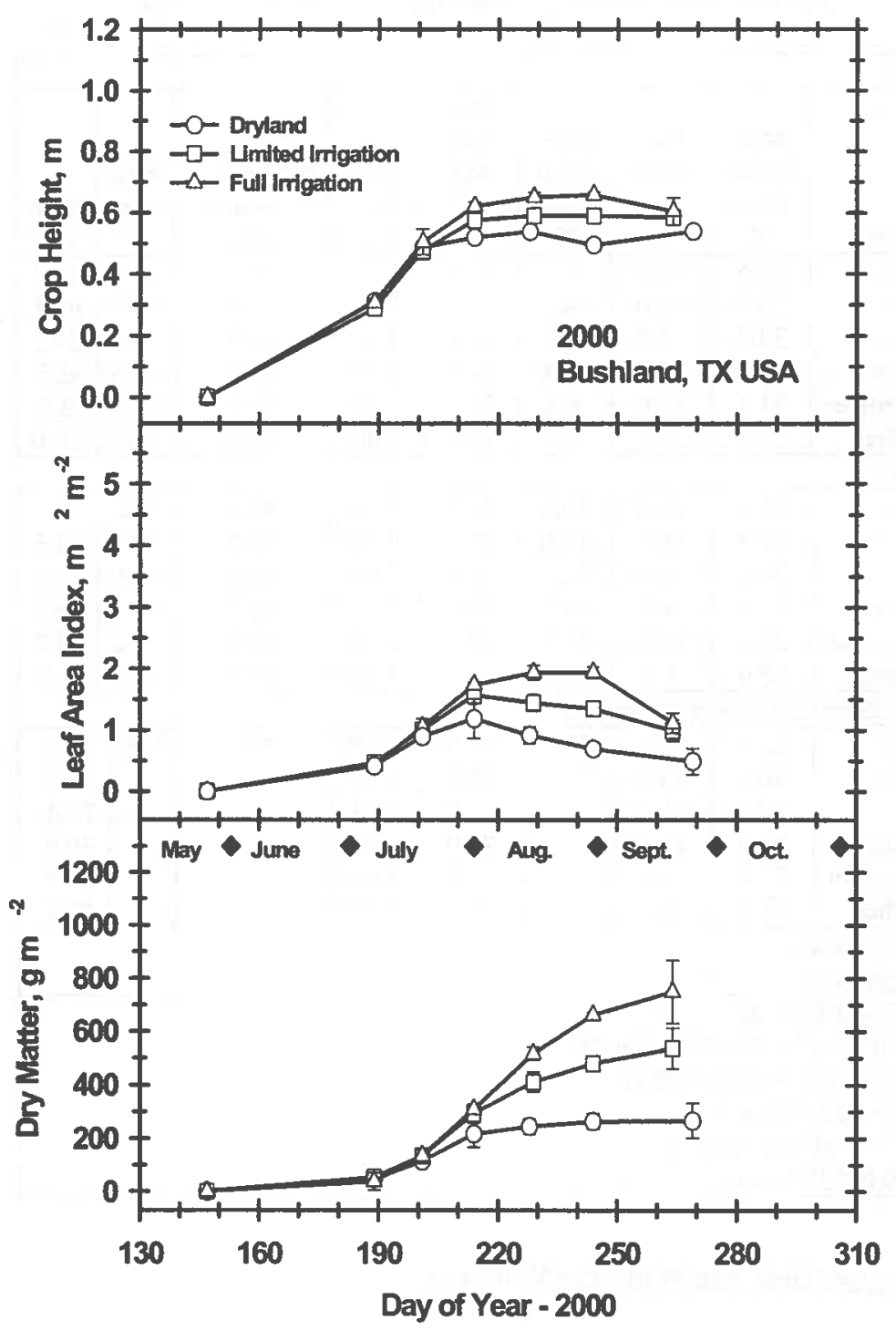

Figure 1. Cotton growth parameters in 2000 at Bushland, TX. $\left[\mathrm{lb} \mathrm{ac}{ }^{-1}=8.92^{*}\left(\mathrm{~g} \mathrm{~m}^{-2}\right) ; \mathrm{ft}=3.28^{*}(\mathrm{~m})\right]$. 


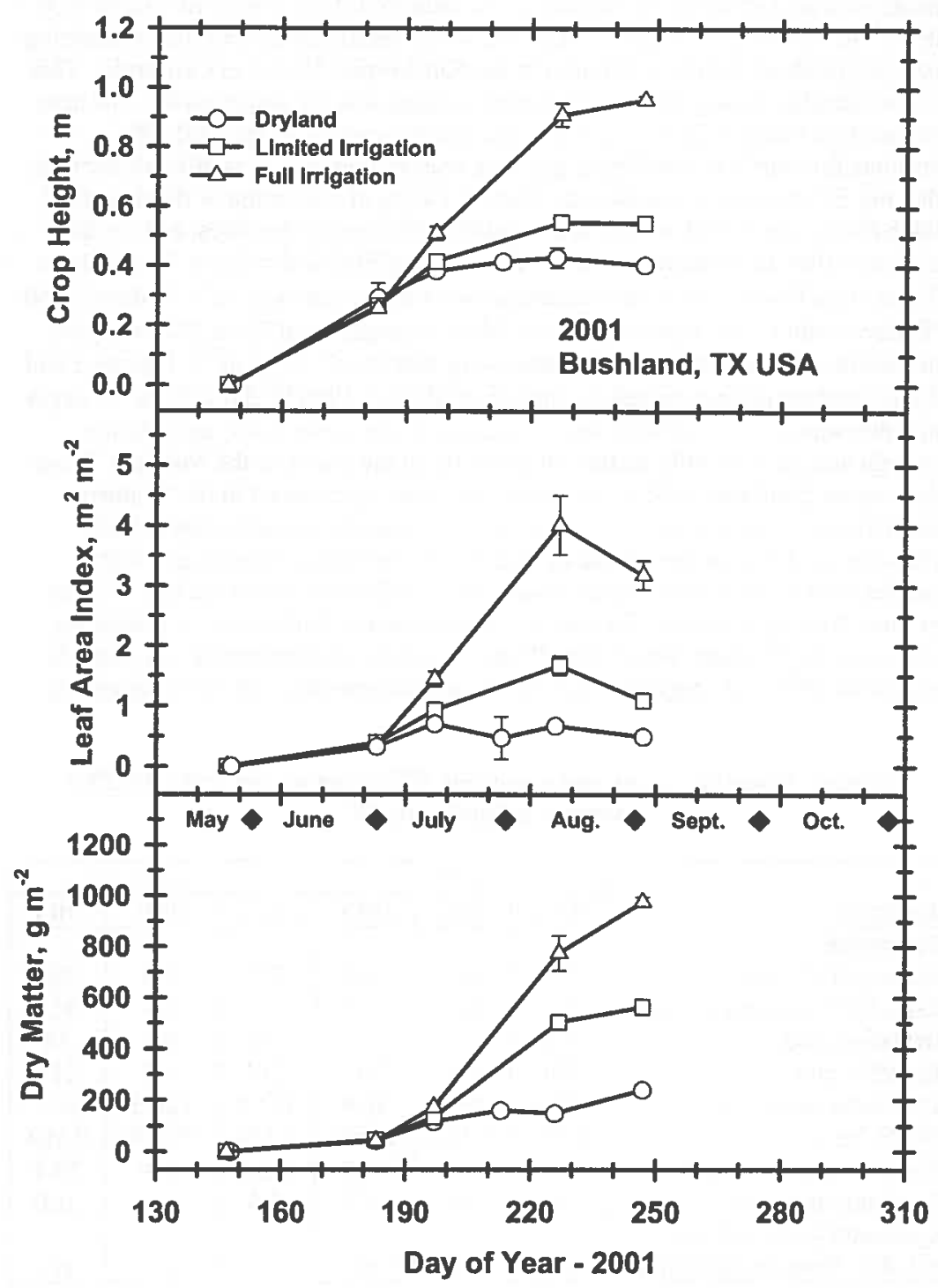

Figure 2. Cotton growth parameters in 2001 at Bushland, TX. $\left[\mathrm{lb} \mathrm{ac}{ }^{-1}=8.92^{*}\left(\mathrm{~g} \mathrm{~m}^{-2}\right) ; \mathrm{ft}=3.28^{*}(\mathrm{~m})\right]$. 
cotton regions around the world. Our ET and WUE for the FULL and DEFICIT treatments are similar to his summary. He indicated WUE values of 43.1 to 47.6 $\mathrm{lb} \mathrm{ac}^{-1}$ in. $^{-1}$ ( 0.19 to $0.21 \mathrm{~kg} \mathrm{~m}^{-3}$ ) required a net irrigation amount (after subtracting rainfall) of about 27.6 in. $(700 \mathrm{~mm}$ ) in the San Joaquin Valley in California. This is considerably greater than our irrigation requirement for cotton on the Northern Texas High Plains [ 20 in. $(\sim 500 \mathrm{~mm})$ or less depending on rainfall]. We attribute this partly to our shorter growing season; however, it is difficult to argue that our ET demand is less than the Central Valley of Califormia or the deserts of High Plains due to high winds, low humidity, relatively clear skies, and the high elevation (low barometric pressure). Peng et al. (1989) indicated in the Southern Texas High Plains, a heat unit accumulation of approximately $2610^{\circ} \mathrm{F}$-days $(1450$ ${ }^{\circ} \mathrm{C}$-days) with a total water supply rainfall plus irrigation of 22 in. $(550 \mathrm{~mm})$ are needed to achieve optimum yields exceeding $624 \mathrm{lb} \mathrm{ac}^{-1}\left(70 \mathrm{~g} \mathrm{~m}^{-2}\right)$. Figures 3 and 4 indicated we did not exceed a cumulative GDD of $1980^{\circ} \mathrm{F}$-days $\left(1100^{\circ} \mathrm{C}\right.$-days) in either season. It is unlikely that a cotton crop can consistently accumulate enough heat units to fully mature all the bolls on the plants in the Northern Texas Arizona or California with the extreme advection experienced in the Southern High Plains environment. It is critical that the first and second position bolls (Hake et al., 1990) be developed by minimizing early crop stresses and that careful insect and disease control measures are utilized to avoid the loss of these primary fruiting positions. Despite the environmental limitations for producing cotton on the Northern Texas High Plains, excellent yield potentials are possible even with DEFICIT irrigations and WUE values exceeding that for many others

Table 4. Water use, yield, and lysimeters WUE data for the 2000 and 2001 seasons at Bushland, TX.

\begin{tabular}{|c|c|c|c|c|c|c|}
\hline \multirow[b]{2}{*}{ Treatment } & \multicolumn{3}{|c|}{2000} & \multicolumn{3}{|c|}{2001} \\
\hline & FULL & DEF. & DRY & FULL & DEF. & DRY \\
\hline Parameters & & & & & & \\
\hline Measured ET, mm & 775 & 622 & 397 & 739 & 578 & 386 \\
\hline FAO-56 Computed ET, mm & 770 & 619 & 356 & 736 & 639 & 415 \\
\hline Irrigation, $\mathrm{mm}$ & 470 & 307 & 12 & 385 & 208 & 14 \\
\hline Rainfall, mm & 201 & 201 & 201 & 214 & 214 & 214 \\
\hline Lysimeter yield, $\mathrm{g} \mathrm{m}^{-2}$ & 150.0 & 89.4 & 36.4 & 111.9 & 126.5 & 39.7 \\
\hline WUE, $\mathrm{kg} \mathrm{m}^{-3}$ & 0.194 & 0.144 & 0.092 & 0.151 & 0.219 & 0.103 \\
\hline Field mean yield, $\mathrm{g} \mathrm{m}^{-2}$ & 131.3 & 64.6 & 25.8 & 102.2 & 91.9 & 28.4 \\
\hline Field std. dev., $\mathrm{g} \mathrm{m}^{-2}$ & 13.3 & 4.8 & 3.7 & 9.6 & 9.0 & 21.0 \\
\hline Lysimeter yield within \pm 2 & & & & & & \\
\hline std. dev. from the field yield & yes & no & no & yes & no & yes \\
\hline $\begin{array}{l}\text { in. }=0.03937^{*}\left(\mathrm{~mm}^{2}\right) \\
\mathrm{lb} \mathrm{ac}=8.92^{*}\left(\mathrm{~g} \mathrm{~m}^{-2}\right) \\
\mathrm{lb} \mathrm{ac}^{-1} \text { in }^{-1}=226.6^{*}\left(\mathrm{~kg} \mathrm{~m}^{-3}\right)\end{array}$ & & & & & & \\
\hline
\end{tabular}



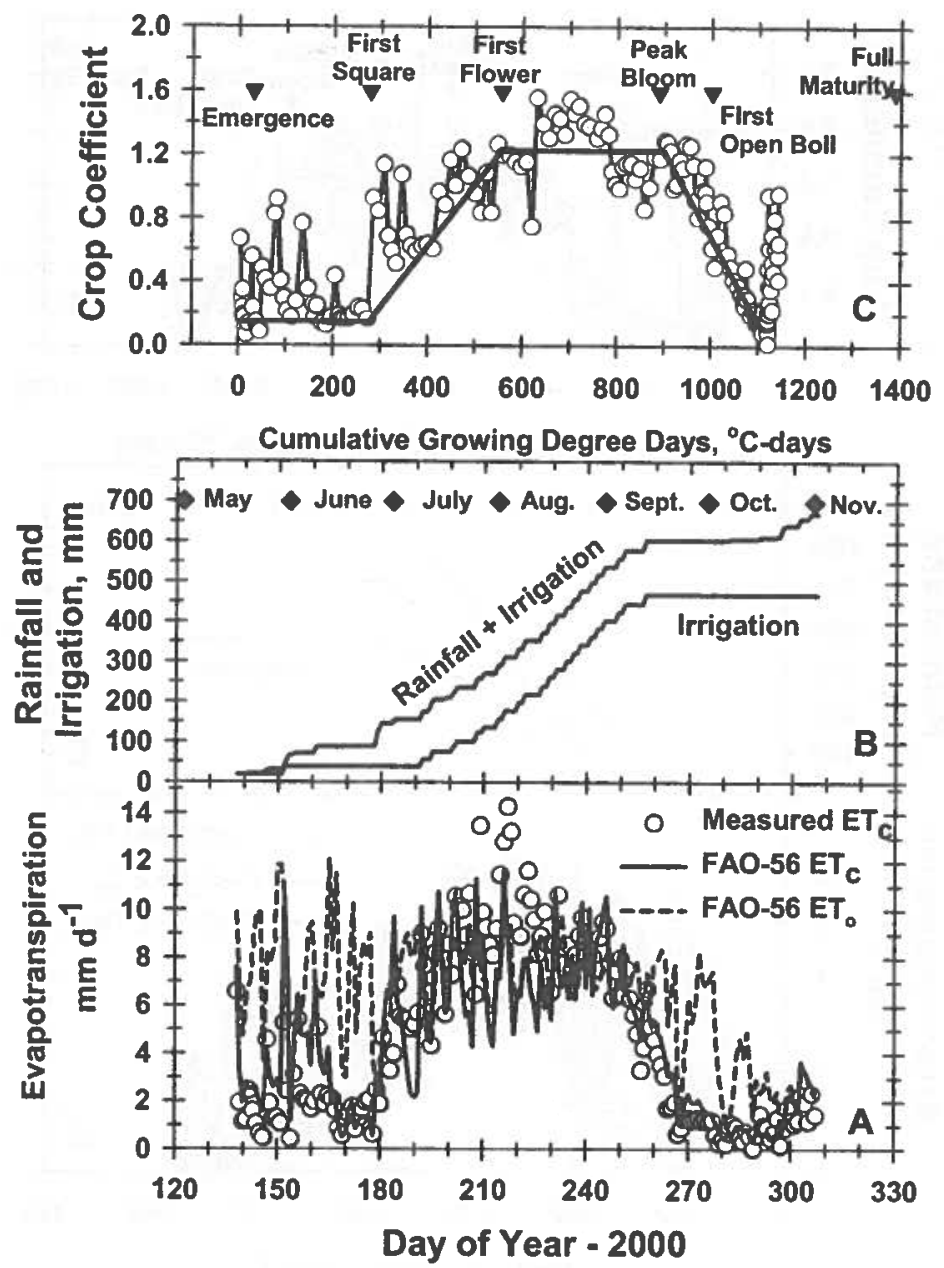

Figure 3. Cotton Water Use for the Full Treatment in 2000at Bushland, TX. (A) Shows the Daily ET $\left(\mathrm{ET}_{\mathrm{c}}\right)$ Measured and Computed by FAO-56 and the FAO ET Reference ET; (B) Shows the Cumulative Irrigation and Rainfall Data; and (C) Shows the Cotton Crop Coefficient in Relation to the Cumulative GDD for the

Base Temperature of $60^{\circ} \mathrm{F}\left(15.6^{\circ} \mathrm{C}\right)$. ET in in. $\mathrm{d}^{-1}=0.03937^{*}\left(\mathrm{~mm} \mathrm{~d}^{-1}\right)$; in. $=0.03937^{*}(\mathrm{~mm}) ; \mathrm{GDD}$ (base $60^{\circ} \mathrm{F}$-days) $=1.8^{*} \mathrm{GDD}$ (base $15.6^{\circ} \mathrm{C}$-days). 

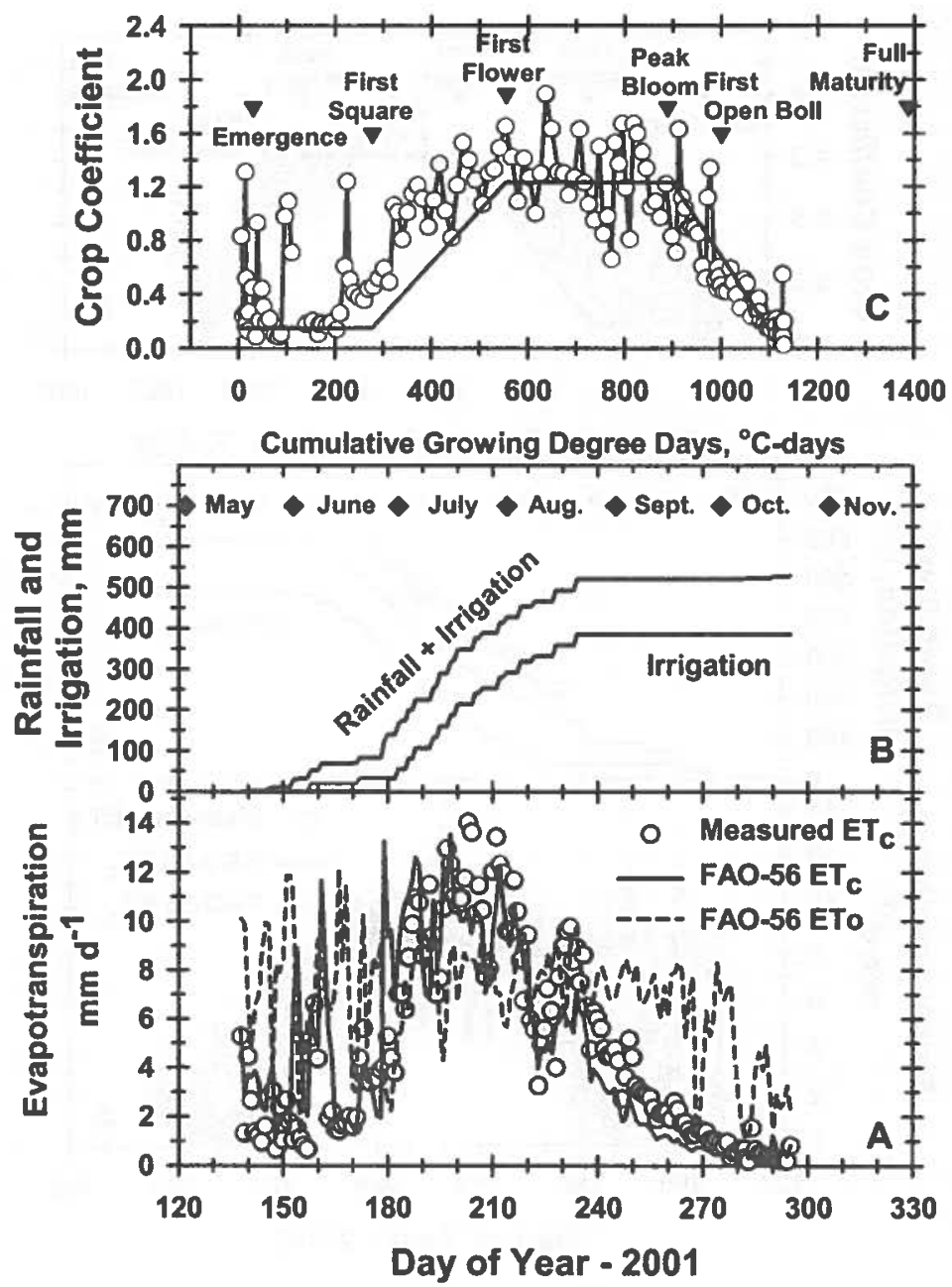

Figure 4. Cotton Water Use for the Full Treatment in 2001 at Bushland, TX. (A) Shows the Daily ET $\left(\mathrm{ET}_{\mathrm{c}}\right)$ Measured and Computed by FAO-56 and the FAO ET Reference ET; (B) Shows the Cumulative Irrigation and Rainfall Data; and (C) Shows the Cotton Crop Coefficient in Relation to the Cumulative GDD for the Base Temperature of $60^{\circ} \mathrm{F}\left(15.6^{\circ} \mathrm{C}\right)$. ET in in. $\mathrm{d}^{-1}=0.03937^{*}\left(\mathrm{~mm} \mathrm{~d}^{-1}\right)$; in. $=0.03937^{*}(\mathrm{~mm}) ; \mathrm{GDD}$ (base $60^{\circ} \mathrm{F}$-days) $=1.8^{*} \mathrm{GDD}$ (base $15.6^{\circ} \mathrm{C}$-days). 
regions with better environments for cotton (Table 4). Cotton offers regional producers another crop option that has a lower water requirement yet a high income potential depending on the fiber quality and price.

The FAO-56 used the computed reference $\mathrm{ET}_{0}$ values for the site with the beginning soil water contents matched to the early season measurements. The FAO-56 model fit the FULL treatments considerably better than the water deficit DRY treatments (Table 5). We believe, without the benefit of a thorough analysis, that the simple "straight line" water stress function, $\mathrm{K}_{\mathrm{s}}$, exaggerated the

Table 5. Model evaluation parameters for the FAO-56 procedure for cotton on the Northern Texas High Plains.

\begin{tabular}{|c|c|c|c|c|c|c|}
\hline & \multicolumn{3}{|c|}{2000} & \multicolumn{3}{|c|}{2001} \\
\hline Treatment & FULL & DEF. & $\mathrm{DRY}$ & $\overline{\text { FULL }}$ & DEF. & $\overline{D R Y}$ \\
\hline Parameters & & & & & & \\
\hline D (Willmott, 1981) & 0.773 & 0.469 & 0.391 & 0.961 & 0.529 & 0.274 \\
\hline $\mathrm{E}(\mathrm{L} \& \mathrm{M}, 1999)$ & 0.562 & 0.897 & 0.007 & 0.710 & 0.311 & -0.498 \\
\hline RMSE, $\mathrm{mm} \mathrm{d}^{-1}$ & 1.98 & 2.48 & 1.83 & 5.83 & 2.39 & 1.87 \\
\hline Mean, $\mathrm{mm} \mathrm{d}^{-1}$ & 4.59 & 3.71 & 2.44 & 4.74 & 3.68 & 2.45 \\
\hline Std. Dev., $\mathrm{mm} \mathrm{d}^{-1}$ & 3.66 & 2.35 & 1.51 & 3.82 & 2.48 & 1.21 \\
\hline Coeff. of Determin., $r^{2}$ & 0.708 & 0.519 & 0.432 & 0.758 & 0.356 & 0.078 \\
\hline
\end{tabular}

on-set of ET stress, although we found the "p" value (stress set point) rather insensitive in our case with trials for $0.4<p<0.8$. The soil water stress function is critical in our case because of deficit, declining water supplies and dryland production. In addition, like Tolk and Howell (2001), we found that the early soil water evaporation was over-estimated which caused the simulated and measured $\mathrm{ET}_{\mathrm{c}}$ values to depart from synchronization WITH THE fao-56 model. The index of agreement (D) (Willmott, 1981) had higher values for the FULL treatments while the modified index of model efficiency (Legates and McCabe, 1999) indicated poorer model agreement, except for the DEFICIT treatment in 2000.

For the Northern Texas High Plains, Table 6 presents a starting point in the use of FAO-56 methods for cotton in this unusual region for cotton. Figures 3 and 4 illustrate the superiority of the GDD basis for crop $\mathrm{K}_{\mathrm{c}}$ curves because the GDD scale spreads the critical mid-season period while maintaining the needed precision on the season ends. Although we did not present the $\mathrm{K}_{\mathrm{c}}$ curves based on a time scale (see Table 6), they required some greater skill in defining the water stress at the end of the mid-season and through the late-season periods. The late season crop coefficients are typically not "adjusted" in FAO-56. But cotton production in this region is often terminated by chemical applications to hasten boll opening and to terminate vegetative growth. Early frost can terminate growth, too, in this region. 
Table 6. Length of cotton growth stages, $\mathrm{K}_{\mathrm{cb}}$, and $\mathrm{K}_{\mathrm{cb}}$ adj values for use with the FAO-56 methods for the Northern Texas High Plains.

\begin{tabular}{|c|c|c|c|}
\hline Cotton Growth Stage & $\begin{array}{l}\text { Length of Stage } \\
\text { (days) }\end{array}$ & $\begin{array}{c}\text { Basal Crop } \\
\text { Coefficient } \\
\left(\mathrm{K}_{\mathrm{cb}}\right)\end{array}$ & $\begin{array}{c}\text { Adjusted Crop } \\
\text { Coefficient } \\
\left(\mathrm{K}_{\mathrm{cb}} \text { adj)\& }\right.\end{array}$ \\
\hline Days & & & \\
\hline Initial & $40-50$ & 0.08 & 0.15 \\
\hline Development & 40 & na & na \\
\hline Mid-season & 50 & 1.10 & 1.23 \\
\hline Late-season & $28-30$ & 0.15 & 0.20 \\
\hline GDDs ( ${ }^{\circ} \mathrm{C}$-days) & & & \\
\hline Initial & $0-277$ & 0.08 & 0.15 \\
\hline Development & 277.555 & na & na \\
\hline Mid-season & $555-900$ & 1.10 & 1.23 \\
\hline Late-season & $900-1100$ & 0.15 & 0.20 \\
\hline
\end{tabular}

\section{CONCLUSIONS}

Cotton appears to be a viable alternate crop for the Northern Texas High Plains that can use less water than other crops. The WUE and yield obtained at Bushland rivals those from more noted cotton production regions while offering a crop alternative that responds well to both rainfall and irrigation. The WUE was almost doubled by irrigation. It is noted that these were unusually dry summers.

The FAO-56 ET procedures performed considerably better under the more "wellwatered" conditions suggesting the need for additional studies on the model's performance or environmental characterization for deficit irrigation and dryland conditions.

\section{Acknowledgements}

The assistance of Karen Copeland, Soil Scientist; Keith Brock, Biological Technical; Brice Ruthardt, Biological Technician; and Don McRoberts, Biological Technician at the Conservation and Production Research Laboratory were vital to this work as well as advice from Dr. Louis Baumhardt, Soil Scientist, on technical aspects of cotton production. 


\section{REFERENCES}

Allen, R. G. 1999. Accuracy of predictions of project-wide evapotranspiration using crop coefficients and reference evapotranspiration. pp. 15-27. In G. Davids and S. Anderson (eds.), Proceedings of the USCID Conference on Benchmarking Irrigation System Performance Using Water Measurement and Water Balances, Presented 10-13 March, San Luis Obispo. CA. USCID, Denver, CO. 13 p.

Allen, R. G. 2000. Using the FAO-56 dual crop coefficient method over an irrigated region as part of an evapotranspiration intercomparison study. $J$. Hydrol. 229(1-2): 27-41.

Allen, R. G., Periera, L. S., Raes, D., and Smith, M. 1998. Crop evapotranspiration: Guidelines for computing crop water requirements. Irrig. and Drain. Paper No. 56. Rome, Italy: United Nations, Food and Agric. Org.

Ayars, J. E., and Hutmacher, R. B. 1994. Crop coefficients for irrigating cotton in the presence of groundwater. Irrig. Sci. 15(1):45-52.

Doorenbos, J., and Pruitt, W. O. 1975. Crop water requirements. Irrig. and Drain. Paper No. 24. Rome, Italy: United Nations, Food and Agric. Org.

Evett, S.R., and Steiner, J. L. 1995. Precision of neutron scattering and capacitance type soil water content gauges from field calibrations. Soil Sci. Soc. Am. J. 59(4):961-968.

Fry, K. E. 1983. Heat-unit calculations in cotton crop and insect models. Adv, in Agric. Tech., A AT-W-23, U. S. Dept. of Agric., Agric. Res. Service, Cotton Res. Ctr., Phoenix, AZ. 23 p.

Grismer, M. E. 2002. Regional cotton lint yield, $\mathrm{ET}_{\mathrm{c}}$, and water value in Arizona and California. Agric. Water Manage. 54(3):227-242.

Hake, K., El-Zik, K., Johnson-Hake, S., and Mauney, J. 1990. Cotton growth and development for production agriculture. Natl. Cotton Council of Am., Memphis, TN. p. 17

Howell, T. A., Schneider, A. D., Dusek, D. A., Marek, T. H., and Steiner, J. L. 1995a. Calibration and scale performance of Bushland weighing lysimeters. Trans. ASAE 38(4):1019-1024.

Howell, T. A., Steiner, J. L., Schneider, A. D., and Evett, S. R. 1995 b. Evapotranspiration of irrigated winter wheat - Southem High Plains. Trans. ASAE 38(3):745-759.

Howell, T. A., Steiner, J. L., Schneider, A. D., Evett, S. R., and Tolk, J. A. 1997. Seasonal and maximum daily evapotranspiration of irrigated winter wheat, sorghum, and corn - Southern High Plains. Trans. ASAE 40(3)623-634. 
Hunsaker, D. J. 1999. Basal crop coefficients and water use for early maturity cotton. Trans. ASAE 42(4): 927-936.

Jensen, M. E., Robb, D. C. N., and Franzoy, C. E. 1970. Scheduling irrigations using climate-crop-soil data. J. Irr. Drain. Div. Am. Soc. Civil Engr. 96(IR1): 25-38.

Jensen, M. E., Wright, J. L., and Pratt, B. J. 1971. Estimating soil moisture depletion from climate, crop, and soil data. Trans. ASAE 14(5): 954-959.

Kerr, G., Pochop, L., Fornstrom, K. J., Krall, J. M., and Brown, D. 1993. Soil water and ET estimates for a wide range of rainfed and irrigated conditions. Agric. Water Manage. 24(2): 147-159.

Legates, D. R., and McCabe, G. J., Jr. 1999. Evaluating the use of "goodness-offit" measures in hydrologic and hydroclimatic model validation. Water Resourc. Res. 35(1): 233-241.

Marek, T. H., Schneider, A. D., Howell, T. A., and Ebeling, L. L. 1988. Design and construction of large weighing monolithic lysimeters. Trans. ASAE 31(2):477-484.

Musick, JT, Pringle, FB, and Walker, JD. (1988). Sprinkler and furrow irrigation trends -Texas High Plains. Appl. Engr. Agric. 4(1):46-52.

Peng, S., Krieg, D. R., and Hicks, S. K. 1989. Cotton lint yield response to accumulated heat units and soil water supply. Field Crops Res. 19:253262.

Sammis, T. W., Mapel, C. L., Lugg, D. G., Lansford, R. R., and McGuckin, J. T. 1985. Evapotranspiration crop coefficients predicted using growing degree days. Trans. ASAE 28(3):773-780.

Slack, D. C., Martin, E. D., Sheta, A. E., Fox, F. A., Jr., Clark, L. J., and Ashley, R. O. 1996. Crop coefficients normalized for climatic variability with growing-degree-days. pp. 892-898. In C.R. Camp, E. J. Sadler, and R. E. Yoder (eds.) Proc. Intl. On Evapotranspiration and Irrigation Scheduling, San Antonio, TX 3-6 Nov., Am. Soc. Agric, Engr., St. Joseph, MI.

Snyder, R., and Pruitt, W. O. 1985. Estimating reference evapotranspiration with hourly data. In R. Snyder, D. W. Henderson, W. O. Pruitt, and A. Dong (eds.), California Irrigation Management Information System Final Report, VIII-3, Land, Air and Water Resour. Paper No. 10013-A, Univ. of Calif., Davis.

Stegman, E. C. 1988. Corn crop curve comparison. Appl. Engr. Agric. 4(3):226233.

Taylor, H. M., Van Doren, C. E., Godfrey, C. L., and Coover, J. R. 1963. Soils of the southwestem Great Plains field station. Misc. Publ.- MP-669, Texas Agric. Exp. Stat., College Station. 
Tolk, J. A., and Howell, T. A. 2001. Measured and simulated evapotranspiration of grain sorghum with full and limited irrigation in three High Plains soils. Trans. ASAE 44(6): 1553-1558.

Unger, P. W., and Pringle, F. B. 1981. Pullman soil: Distribution, importance, variability, and management. Bull. 13 - 1372, Texas Agric. Exp. Stat., College Station.

USDA, National Agricultural Statistics Service. 2001. Corn for grain 2001, yields per harvested acre by county. USDA-NASS web site, http://www.usda.gov/nass/graphics/county01/cryld.htm (viewed on April 20, 2002).

Willmott, C. J. 1981. On the validation of models. Phys. Geog. 2(2):184-94.

Wright, R. L. 1982. New evapotranspiration crop coefficients. J. Irrig. and Drain Div. Am. Soc. Civil Engr.:108(IR2):57-74 